\title{
Evaluation of Cow Based Bio-Enhancers on Production of Broccoli (Brassica oleracea)
}

\section{Ravi Prakash Mishra ${ }^{1 *}$, Himanshu Trivedi ${ }^{2}$, Deepali Bakshi ${ }^{1}$, Vibhuti Gupta ${ }^{1}$ and Vivekanand Yadav ${ }^{2}$}

${ }^{1}$ Department of Agriculture, CGC Technical Campus, Jhanjeri (Mohali), Punjab-140307, India

${ }^{2}$ School of Agrl. Sci. \& Engineering, IFTM University, Moradabad (UP)- 244001, India

${ }^{3}$ Department of Genetics and Plant Breeding, CSAUAT, Kanpur-208002, India

K e y w o r d s
Broccoli, Bio-
enhancers,
Panchgavya,
Jivamrita,
Vermiwash
Article Info
Accepted:
22 November 2020
Available Online:
10 December 2020

\section{Ke y w o r d s}

Broccoli, Bioenhancers,

Panchgavya,

Jivamrita,

Article Info

Accepted:

22 November 2020

10 December 2020

\section{A B S T R A C T}

Seeing the adverse impact of excessive use of agrochemicals on soil health and environment, Government of India promotes organic farming. Number of cow-based bio-enhancers like 'Bijamrut', 'Jivamrita', 'Panchgavya', 'Amrutpani', 'Sanjivak' etc. have been developed in different organic farming systems. In this investigation total 07 treatments [Control, Panchgavya (4\%), Jivamrita (20\%), Vermiwash (1:5 time dilution), Panchgavya (4\%)+Jivamrita (20\%), Panchgavya (4\%) + Vermiwash (1:5 time dilution), Jivamrita (20\%) +Vermiwash (1:5 time dilution) were used and excellent results were observed of Panchgavya (4\%) and Panchgavya $(4 \%)+$ Jivamrita $(20 \%)$ in different characters e.g. Days to first visible curd, Length of stem, Length of stem, Diameter of stems, Weight of curd, Diameter of curd, Yield/plot and Yield/ha.

\section{Introduction}

Seeing the adverse impact of excessive use of agrochemicals on soil health and environment, Government of India promotes organic farming. Organic farming has been included as a special category of farming in the National Agriculture Policy approved by the Government of India during 2000. The policy seeks to actualize the area and crop potential for organic farming, sustaining soil fertility, conserving bio-resources, strengthening rural economy, promoting value addition, accelerating the growth of agrobusiness and securing a fair standard of living for the farmers and agricultural workers and their families.

For effective implementation of the policy, there is an urgent need to develop a composite 
package of practices for major crops of the region. Numbers of cow-based bio-enhancers like 'Bijamrut', 'Jivamrita', 'Panchgavya', 'Amrutpani', 'Sanjivak' etc. have been developed in different organic farming systems by innovative organic growers (Mahmad A. Shekh et al., 2018). In Ayurveda, there is a long tradition of using cow products for positive health, pharmaceutical processes and in therapeutics. There are Sutras in classical texts on the varied properties of milk, curds, ghee, urine, bile, feces, horns etc. from different animals. In a very popular and widely followed book 'Arya-Bhishak' by Vaidya Shankar DajiPade, there is a chapter on 'Govaidyak'. He has described the properties and uses of cow's milk, curds, butter, buttermilk, ghee, urine, feces and dung-ash. However, he has not dealt with Panchgavya which is a combination product of five ingredients viz. milk, curds, ghee, urine and feces of cows (Raut et al., 2018). There have been quite a few studies on the activity, efficacy, safety and acceptability of Panchgavya and other cow products (Dhama et al., 2014). Pathak has described the bio-enhancing effects of Panchgavya and other cow products in horticulture (Pathak et al., 2013). Panchgavya has many beneficial implications in agriculture, organic farming as good quality natural manure and biopesticides, as alternate energy resources and high medicinal values (Dhama et al., 2005). Bio-enhancers are organic preparations, obtained by active fermentation of animal and plant residues over specific duration. These are rich sources of microbial consortia, macro, micronutrients and plant growth promoting substances including immunity enhancers. In general these are utilized to treat seeds/seedlings, enhance decomposition of organic materials thereby enrich soil and induce better plant vigour (Pathak and Ram, 2013). "Cow" plays a key role in most of the organic farming systems prevalent in India and elsewhere (Pathak et al., 2010). Vermiwash is a liquid that is collected after the passage of water through a column of worm action and is very useful as a foliar spray. It is a collection of excretory products and mucous secretion of earthworms along with micronutrients from the soil organic molecules. These are transported to the leaf, shoots and other parts of the plants in the natural ecosystem.

Vegetables are a rich source of nutrients, important for human health. They are particularly important sources of micronutrient, pro-vitamin- $\mathrm{A}, \mathrm{B}_{6}, \mathrm{C}$ and $\mathrm{E}$ as well as folic acid, iron and magnesium. Vegetables also supply fair amounts of dietary fibers. Due to their high water content and fiber (which constitute a high percentage of complex carbohydrates), leafy vegetables and roots help in digestion and utilization of the more concentrated food in the human diet. Vegetables containing high amounts of fiber are spinach $(6.3 \%)$, peas 95.20 , broad bean (4.2\%) and okra (3.1) (Pandey, 2010). Vegetables are important for human nutrition in terms of bioactive nutrient molecules such as dietary fiber, vitamins and minerals, and non-nutritive phytochemicals (phenolic compounds, flavonoids, bioactive peptides, etc.). These nutrient and non-nutrient molecules reduce the risk of chronic diseases such as cardiovascular diseases, diabetes, certain cancers, and obesity. Vegetables are the fresh and edible portions of herbaceous plants. They are important food and highly beneficial for the maintenance of health and prevention of diseases. They contain valuable food ingredients which can be successfully utilized to build up and repair the body. Vegetables are valuable in maintaining an alkaline reserve of the body (Rumeza Hanif et al., 2006). Broccoli is an edible green plant in the cabbage family (family Brassicaceae, genus Brassica) whose large flowering head and stalk is eaten as a vegetable. The word broccoli comes from the Italian plural of 
broccolo, which means "the flowering crest of a cabbage", and is the diminutive form of brocco, meaning "small nail" or "sprout" ("broccoli". Merriam-Webster's Collegiate Dictionary, $11^{\text {th }}$ ed. 2004). Broccoli is classified in the Italicacultivar group of the species Brassica oleracea. Broccoli has large flower heads, usually dark green in color, arranged in a tree-like structure branching out from a thick stalk which is usually light green.

The mass of flower heads is surrounded by leaves. Broccoli resembles cauliflower, which is a different cultivar group of the same Brassica species. In 2017, China and India combined produced $73 \%$ of the world's broccoli and cauliflower crops (FAOSTAT)2018. Broccoli is rich in vitamin $\mathrm{C}$, dietary ber and also containglucoraphin, sulforaphane, selenium and isothiocyanates. Broccoli is also an excellent source of indole3-carbinol. These constituents present in broccoli are known to be very popular since they possess several anti-cancer properties and benefits. These anti-carcinogenic compounds have a wide variety of uses and benefits for the treatment of various diseases and disorders. Broccoli is widely used in the treatment of several forms of cancer and also treats other neural disorders (Chandini R. 2015).

\section{Materials and Methods}

A field experiment entitled "Evaluation of cow based bio-enhancers on production of broccoli (Brassica oleracea)"was conducted during 2019-20 in the experimental farm of Department of Agriculture, CGC Technical Campus Jhanjeri (Mohali) Punjab. The experiment was laid out in randomized block design (RBD). All treatments were randomly allocated among the plots (size- $2 \times 2.5 \mathrm{~m}$ ) and replicated three times. Total 07 treatments [T0, control; T1, Panchgavya (4\%); T2, Jivamrita (20\%); T3, Vermiwash (1:5 time dilution); T4, Panchgavya (4\%)+Jivamrita (20\%); T5, Panchgavya (4\%)+ Vermiwash (1:5 time dilution); T6, Jivamrita (20\%) +Vermiwash (1:5 time dilution).

\section{Preparation of panchgavya}

Panchgavya is an organic formulation, in Sanskrit, means the blend of five Cow products like cow dung, Cow urine, curd, ghee, milk, and some other important ingredients. All the ingredients added to a wide mouthed plastic can as per order e.g. first poured cow dung $7 \mathrm{~kg}$ and cow ghee $1 \mathrm{~kg}$ mixed thoroughly in morning \& evening and kept that for 3 days. After 3 days cow urine 10 lit \& water 10 lit was mixed and kept that for 15 days with regular mixing in morning and evening. After 15 days, cow milk 3 lit, cow curd $2 \mathrm{~kg}$, coconut water 3 lit, jiggery solution 3 lit and well ripened banana 12 nos. added, kept under shade another for 15 days and was used according to treatments.

\section{Preparation of jivamrita}

Jivamrita is a rich bio-formulation containing consortia of microbes. It is a solution of fermented cow's dung, cow's urine, sugarcane juice, virgin soil and pulse flour. The $7 \mathrm{~kg}$ of fresh cow dung and 10 lit. cow urine were mixed thoroughly in 200 lit of water in a mud pot. Then 4 lit of sugarcane juice, $2 \mathrm{~kg}$ pulse flour and $1 \mathrm{~kg}$ of virgin soil were added in it. The soil under a tree or undisturbed location (chemicals free soil) is considered as a virgin soil. This solution was stirred well and kept for 3 days for fermentation under shade.

The pot of Jivamrita solution was covered with a muslin cloth to avoid any undesirable contamination. After 3 days of fermentation, solution of Jivamrita was prepared and was used according to treatments. 


\section{Preparation of vermiwash}

Vermiwash extracted through vermiwash collecting device which is made up of Mud drum having capacity of 5 liter and a tap at the bottom the drum filled with broken bricks, about $10 \mathrm{~cm}$ thickened which is followed by sand layer of $2-3 \mathrm{~cm}$ thickness lastly with filled with vermin-compost with heavy population of earth worms simultaneously added fresh water in to drum and a container kept bellow the tap of drum. The watery yellowish to black extract of vermin-compost, Vermiwash drained out from drum. After 1 to 2 days the process of extraction has been completed.

\section{Results and Discussion}

The data obtained from investigation was subjected to statistical analysis as per procedure described by Gomez and Gomez (1984). The significance of the treatments was tested through $\mathrm{F}$ test at $5 \%$ and $1 \%$ level of significance. Whereas, the mean analysis was done after testing the significance of the variance ratio of error mean squares.

Significant variation was found in application of different bio-enhancers to improve the vegetative growth and yield of Broccoli. Days to the first visible curd, length of stem, diameter of stem, weight of curd, diameter of curd, yield/plot and yield/ha. showed significant variation to different combinations of bio-enhancers e.g. T1, Panchgavya (4\%); T2, Jivamrita (20\%); T3, Vermiwash (1:5 time dilution); T4, Panchgavya (4\%)+ Jivamrita (20\%); T5, Panchgavya (4\%)+ Vermiwash (1:5 time dilution); T6, Jivamrita (20\%) +Vermiwash (1:5 time dilution) against Control T0. Minimum 52 days from transplanting to the first visible curd was found from T1 and T5 which was statistically similar with T2, T3, T4 and T6 (53) whereas maximum from $\mathrm{T} 0$ (59) (Table 1).

\section{Days to first visible curd}

It is evident from the Table 1 and its corresponding histogram that Minimum 52 days from transplanting to the first visible curd was found from T1, Panchgavya (4\%) and T5, Panchgavya (4\%)+ Vermiwash (1:5 time dilution) which was statistically similar with T2, Jivamrita (20\%); T3, Vermiwash (1:5 time dilution); T4, Panchgavya (4\%)+ Jivamrita (20\%) and T6, Jivamrita (20\%)+Vermiwash (1:5 time dilution) (53) whereas maximum from T0: Control (59).

\section{Length of stem}

It is evident from the result presented Table 1 and its corresponding histogram that, maximum diameter of curd was found T4; :Panchgavya (4\%)+Jivamrita (20\%) (25.4 $\mathrm{cm})$ followed by T1: Panchgavya (4\%) $(24.0$ $\mathrm{cm})$, T5: Panchgavya (4\%)+Vermiwash (1:5 time dilution) $(23.0 \mathrm{~cm}), \mathrm{T} 3$ : Vermiwash $(1: 5$ time dilution) $(22.4 \mathrm{~cm})$, T6: Jivamrita (20\%)+Vermiwash (1:5 time dilution) (21.7 $\mathrm{cm})$ and T2: Jivamrita $(20 \%)(21.5 \mathrm{~cm})$ whereas the diameter in T0: Control (18.0 $\mathrm{cm})$. Most of the similar findings have also been obtained from Pizetta et al., (2005).

\section{Diameter of stem}

It is evident from the result presented Table 1 and its corresponding histogram that, maximum length of stem was found T4: Panchgavya $(4 \%)+$ Jivamrita $(20 \%)(4.7 \mathrm{~cm})$ followed by T1: Panchgavya $(4 \%)(4.6 \mathrm{~cm})$, T2: Jivamrita (20\%) \& T5: Panchgavya $(4 \%)+$ Vermiwash (1:5 time dilution) $(3.9 \mathrm{~cm})$, T3: Vermiwash (1:5 time dilution) $(3.7 \mathrm{~cm})$ and T6: Jivamrita (20\%)+Vermiwash (1:5 time dilution) $(3.5 \mathrm{~cm})$ whereas the diameter in control T0: Control $(3.1 \mathrm{~cm})$. The above results are also corroborated with the findings of Khomami et al., (2004). 


\section{Weight of curd}

It is evident from the result presented Table 1 and its corresponding histogram that, maximum weight of curd was found T4: Panchgavya (4\%)+Jivamrita (20\%) (481 g) followed by T1:Panchgavya (4\%) (454 g), T6: Jivamrita (20\%)+Vermiwash (453 g), T5: Panchgavya (4\%)+ Vermiwash (449 g), T2:Jivamrita (20\%) (403 g) and T3: Vermiwash (1:5 time dilution) $(390 \mathrm{~g})$ whereas the diameter in T0: Control (252 g).

\section{Diameter of curd}

It is evident from the result presented Table 1 and its corresponding histogram that, maximum length of stem was found T4: Panchgavya $(4 \%)+$ Jivamrita $(10.1 \mathrm{~cm})$ followed by T5: Panchgavya (4\%)+ Vermiwash $(9.9 \mathrm{~cm}), \quad$ T1:Panchgavya $(4 \%)$ $(9.4 \mathrm{~cm})$, T6: Jivamrita (20\%)+Vermiwash $(9.3 \mathrm{~cm})$, T2: Jivamrita $(9.2 \mathrm{~cm})$ and T3: Vermiwash (1:5 time dilution) $(8.8 \mathrm{~cm})$ whereas the diameter in T0: Control $(8.5 \mathrm{~cm})$ The present findings are similar to the results as replied by Bhadra, et al., (2019).The present findings are similar to the results as replied by Bakang KedumetseKgasudi and ModiriMantswe (2020).

\section{Yield/plot}

It is evident from the result presented Table 1 and its corresponding histogram that, maximum weight of curd was found $\mathrm{T}$ : Panchgavya $(4 \%)(9.73 \mathrm{~kg})$ followed by $\mathrm{T} 4$ : Panchgavya (4\%)+Jivamrita $(9.0 \mathrm{~kg}), \quad \mathrm{T} 5$ : Panchgavya (4\%)+ Vermiwash (8.83 kg), T2:Jivamrita $(8.67 \mathrm{~kg}), \mathrm{T} 3$ : Vermiwash (1:5 time dilution) $(8.63 \mathrm{~kg})$ and T6: Jivamrita $(20 \%)+$ Vermiwash $(8.5 \mathrm{~kg})$ whereas the diameter in T0: Control $(6.2 \mathrm{~kg})$. The reason behind this higher level of cow based products provided the plant with sufficient nutrients, moisture and other essentials component for proper growth and development which ultimately increased the yield of broccoli per plant. The present findings are similar to the results as replied by Aktar et al., (1996) and Hameed Salih Hammad et al., (2019).

\section{Yield/ha}

It is evident from the result presented Table and its corresponding histogram that, maximum weight of curd was found T1:Panchgavya $4 \%)(19.46$ ton/ha) followed by T4: Panchgavya (4\%)+Jivamrita (18 ton/ha), T5: Panchgavya (4\%)+ Vermiwash (17.66 ton/ha), T2:Jivamrita (17.34 ton/ha), T3: Vermiwash (17.26 ton/ha) and T6: Jivamrita (20\%)+Vermiwash (17.0 ton/ha) whereas the diameter in control T0 (12.4 ton/ha). The present findings are similar to the results as replied by Sharma, R. (2016).

Organic liquid formulations like Panchgavya and Jivamrit contains Rhizobium, Azotobacter, Azospirillum and PSB which act as a source of inoculation in the soil besides providing favourable soil condition facilitated the enhancement in the population of rhizobium and PSB. These findings are in agreement with those reported by Chaudhari (2012). Moreover, bio-enhancers (Panchgavya and Jivamrit) facilitated robust growth of plants and soil health and thereby increased nodulation. Increase in nodulation is directly related to increase in microbial count in soil. Similar findings have been reported by Patel et al., (2013) [9] and Sutharsan and Mohottige (2017). Increase in plant height was also reported by Khomani (2004) in Diffenbachia with Vermiwash, Bhalla et al., (2006a), Kumar et al., (2009) in gladiolus and Bhalla et al., (2006b) and Dharma (2006) in carnation with Panchgavya. A liquid that collected after the passage after of water through a column of worm action popularly known as Vermiwash. 
It is a mixture of excretory products and mucus secretion of earthworms along with micronutrients from the sol organic molecules. It contains nitrogen and growth promoting hormones and essential enzymes that influence resistance in the pants. It is transported to the shoots and other pant parts in the natural ecosystem. It contains cocktail of enzymes viz. Proteins, amylase, urease and phosphates. These are beneficial for growth and development of plant finally stimulate the yield attributing characters and productivity of crops (Kaur, P. et al., 2015). In the present investigation, an increase in yield of Broccoli is the outcome of increase in the dimension of all the yield attributing traits as well know yield is a complex trait which is solely dependent on the curd weight. Nath et al., (2009) reported increased growth yield and fruit quality of trails in case of tomato at (5.10-15) t/ha. Atiyeh et al 2000. Prove the impact of organic fertilizer Vermiwash + Panchgavya in case of groundnut yield and quality. (Garg and Chauhan 2003) and (Saxena et al., 2004) advocated that traditional Panchgavya and Vermiwash, when mixed the soil@ ratio of 1:100 and used as growth medium promoted quit increased, shoot and root weight of the seedling pulses, cereal and vegetables. There by increasing their yield many workers viz. Yoshida et al., (1976), Dutta et al., (2005), Smith and Staden (1983-84), have reported many form of increases in yield attributing traits as aresult of application of Vermiwash and Panchgavya in number of vegetable crops.

Table.1 Response ofdifferent combinations of bio-enhancers on yield of Broccoli

\begin{tabular}{|c|c|c|c|c|c|c|c|}
\hline Treatment & $\begin{array}{l}\text { Days to } \\
\text { first } \\
\text { visible } \\
\text { curd }\end{array}$ & $\begin{array}{l}\text { Length } \\
\text { of stem } \\
\text { (cm) }\end{array}$ & $\begin{array}{l}\text { Diameter } \\
\text { of stem } \\
(\mathrm{cm})\end{array}$ & $\begin{array}{l}\text { Weight } \\
\text { of curd } \\
\quad(g)\end{array}$ & $\begin{array}{l}\text { Diameter } \\
\text { of curd } \\
(\mathrm{cm})\end{array}$ & $\begin{array}{l}\text { Yield/ } \\
\text { Plot } \\
(\text { Kg) }\end{array}$ & $\begin{array}{l}\text { Yield/ } \\
\text { Ha } \\
\text { (Ton) }\end{array}$ \\
\hline T0 : Control & 59 & 18 & 3.1 & 252 & 8.5 & 6.2 & 12.4 \\
\hline $\begin{array}{l}\text { T1: Panchgavya } \\
(4 \%)\end{array}$ & 52 & 24 & 4.6 & 454 & 9.4 & 9.73 & 19.46 \\
\hline T2: Jivamrita (20\%) & 53 & 21.5 & 3.9 & 403 & 9.2 & 8.67 & 17.34 \\
\hline $\begin{array}{l}\text { T3: Vermiwash }(1: 5 \\
\text { time dilution) }\end{array}$ & 53 & 22.4 & 3.7 & 390 & 8.8 & 8.63 & 17.26 \\
\hline $\begin{array}{l}\text { T4: Panchgavya } \\
(4 \%)+\text { Jivamrita } \\
(20 \%)\end{array}$ & 53 & 25.4 & 4.7 & 481 & 10.1 & 9 & 18 \\
\hline $\begin{array}{l}\text { T5: Panchgavya } \\
\text { (4\%)+Vermiwash } \\
\text { (1:5 time dilution) }\end{array}$ & 52 & 23 & 3.9 & 449 & 9.9 & 8.83 & 17.66 \\
\hline $\begin{array}{l}\text { T6: Jivamrita } \\
(20 \%)+\text { Vermiwash } \\
\text { (1:5 time dilution) }\end{array}$ & 53 & 21.7 & 3.5 & 453 & 9.3 & 8.5 & 17 \\
\hline S.EM & 0.96 & 0.506 & 0.079 & 4.43 & 0.149 & 0.213 & 0.471 \\
\hline CD (5\%) & 2.94 & 1.559 & 0.242 & 13.6 & 0.459 & 0.658 & 1.451 \\
\hline
\end{tabular}




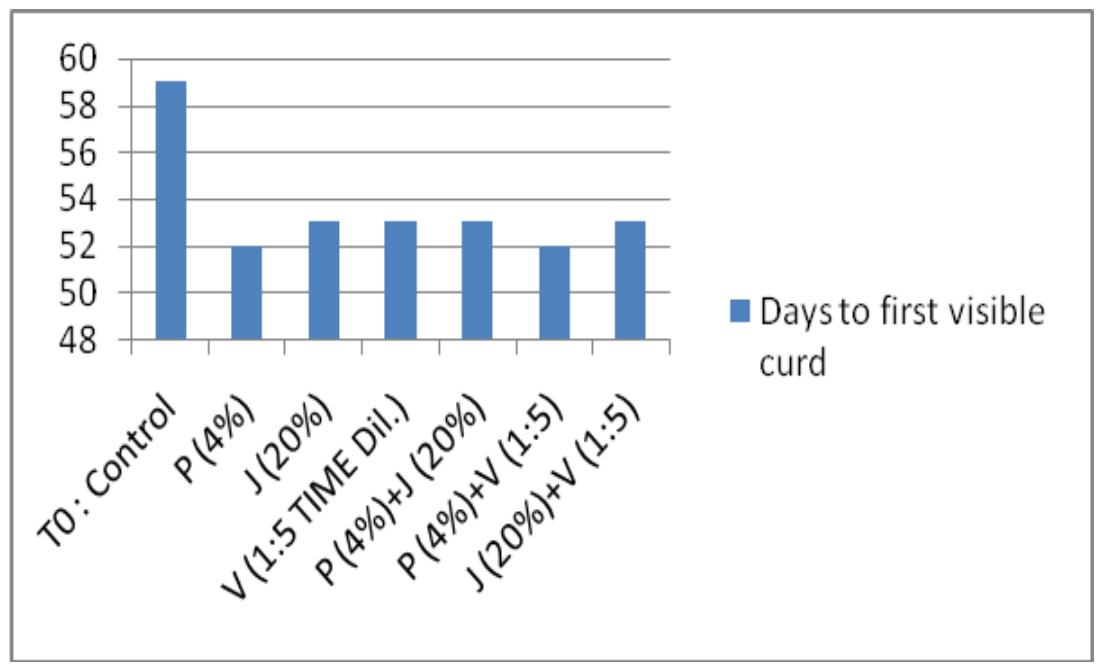

Fig.1 Days to first visible

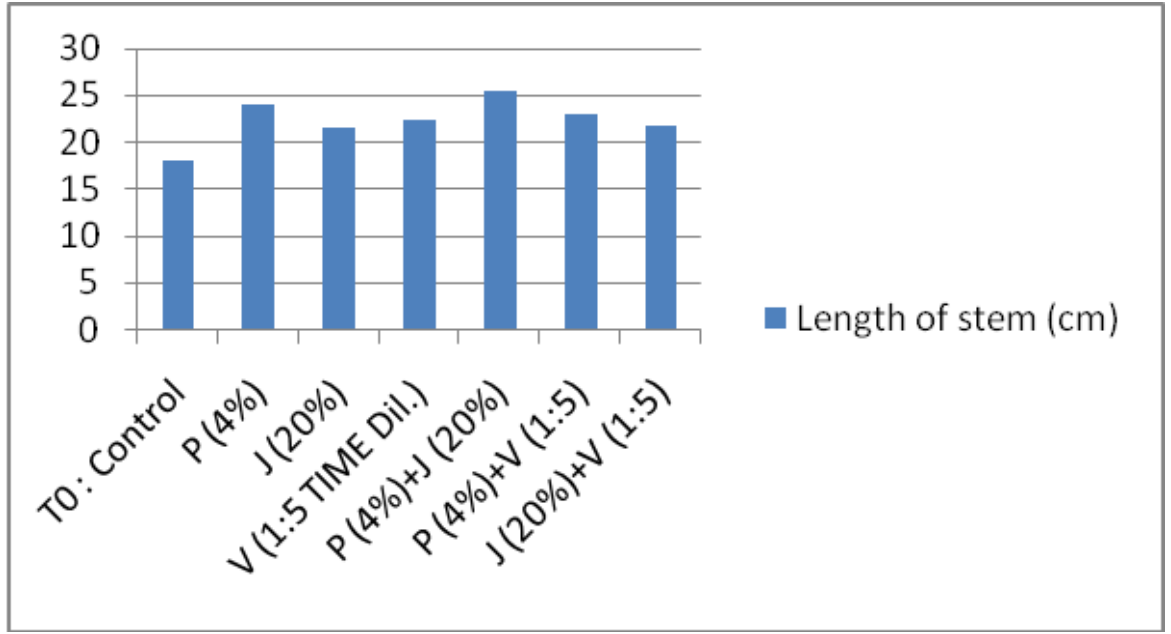

Fig.2 Length of stem $(\mathrm{cm})$

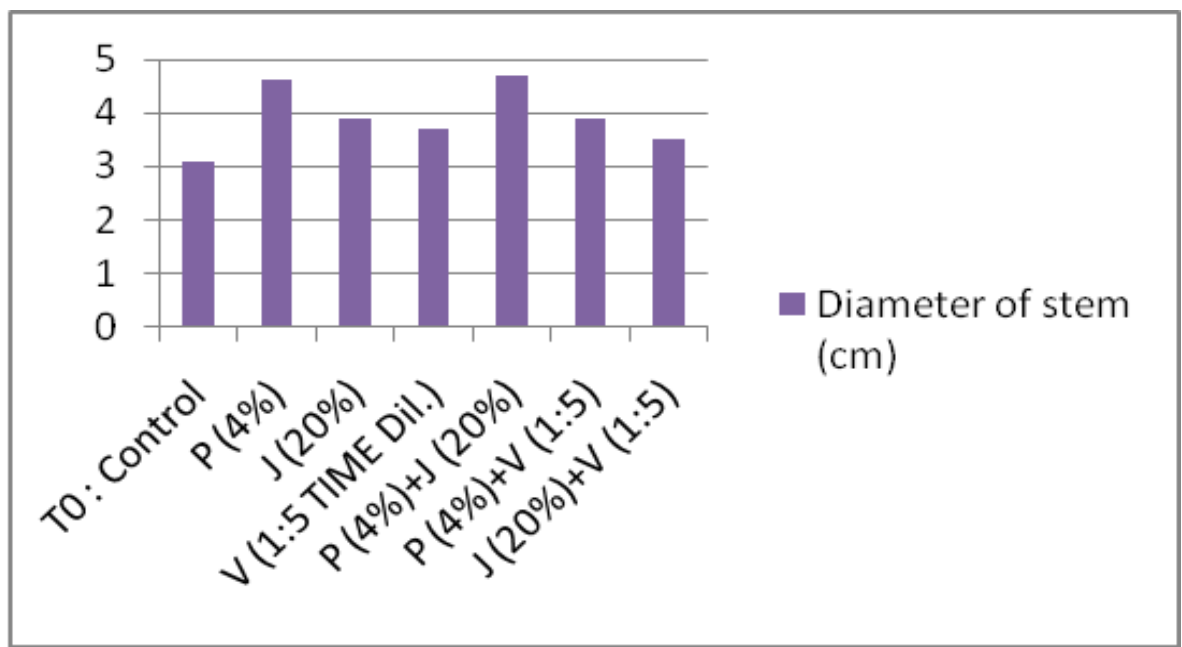

Fig.3 Diameter of stem (cm) 


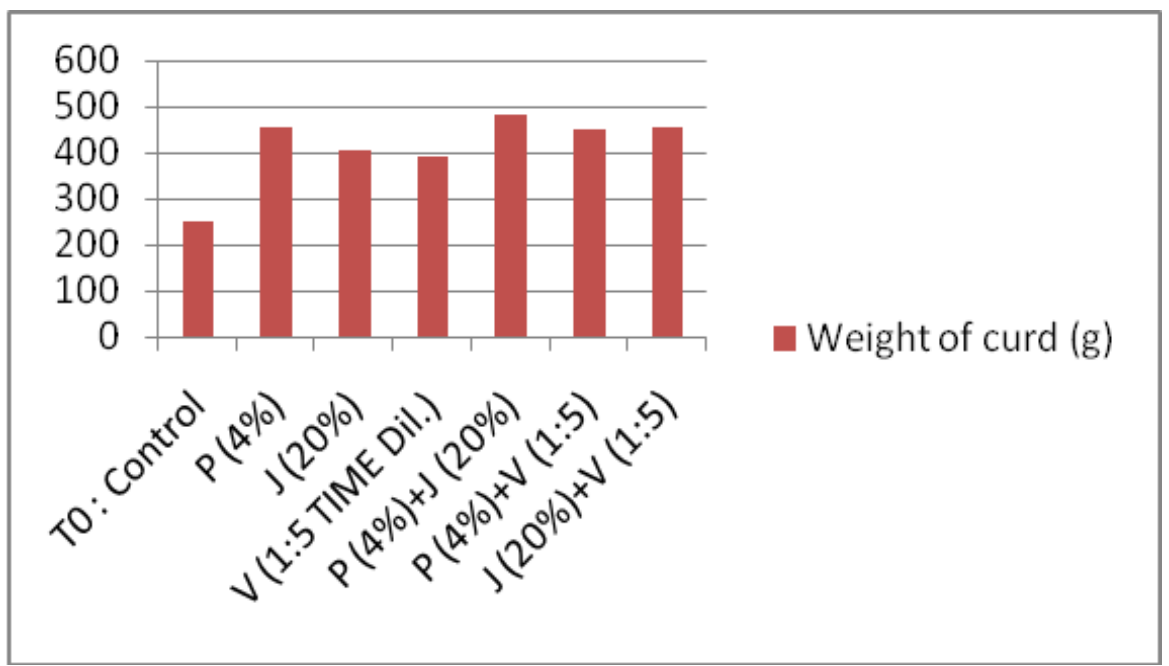

Fig.4 Weight of curd (g)

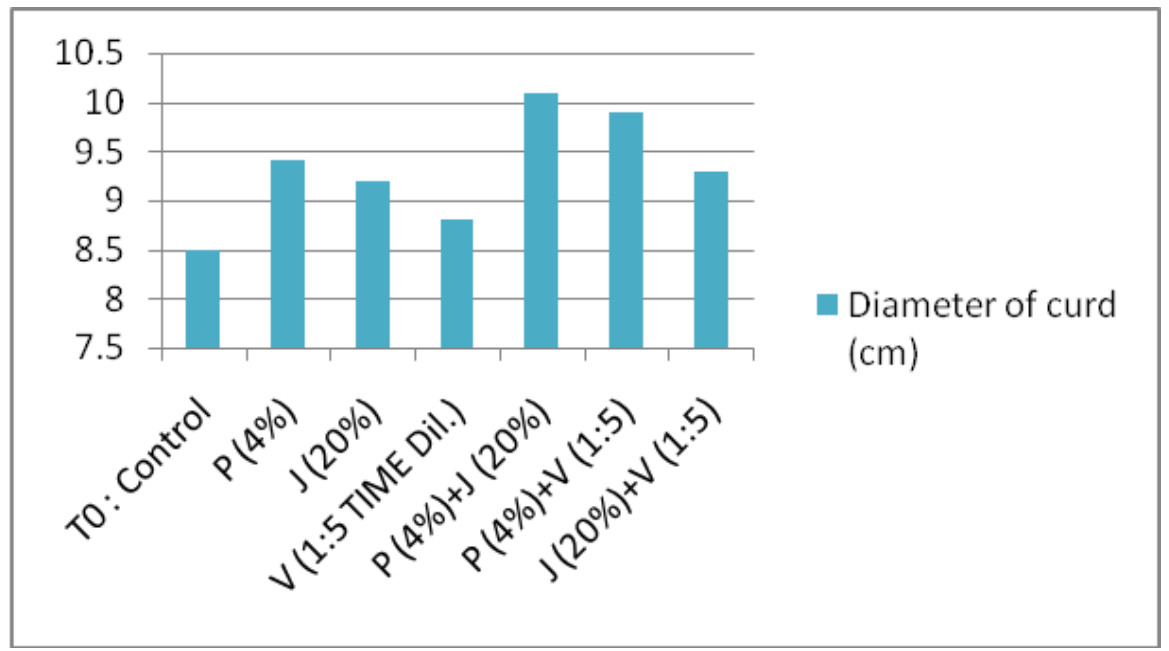

Fig.5 Diameter of curd (cm)

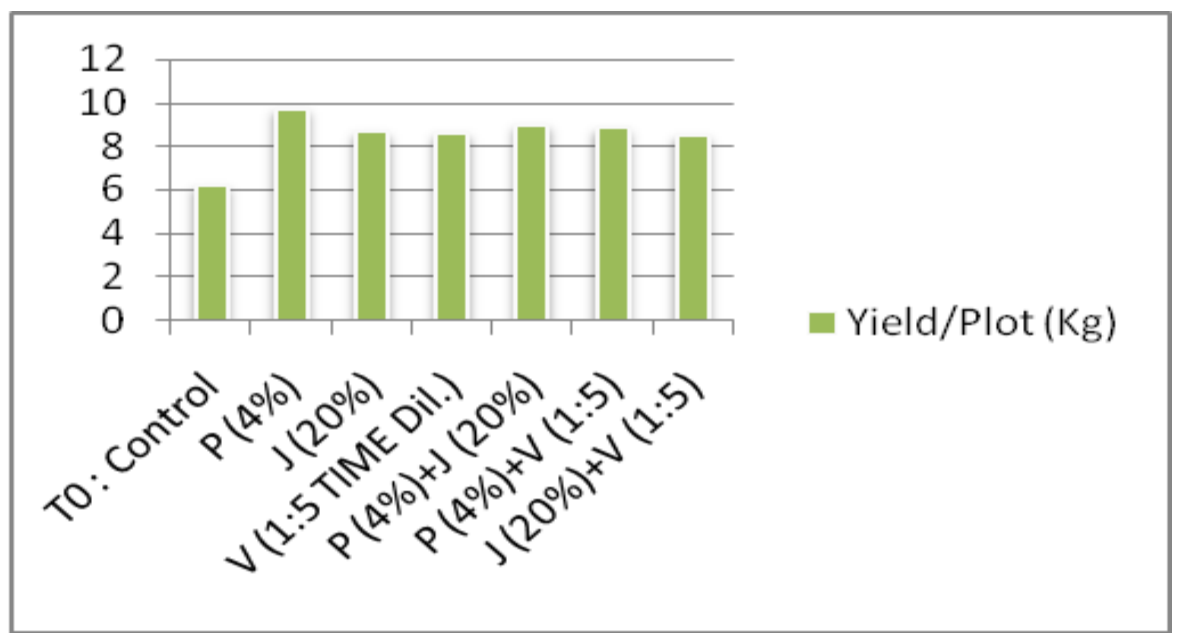

Fig.6 Yield/Plot (Kg) 


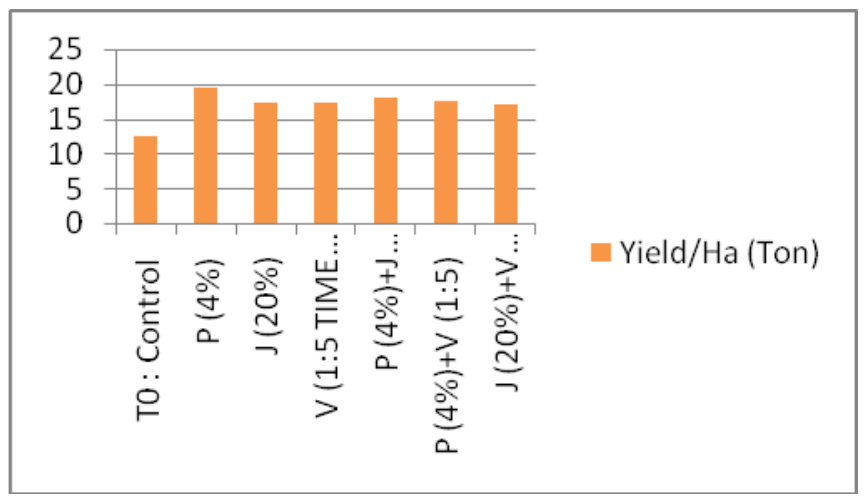

Fig.7 Yield/Ha (Ton)

On the basis of above findings it can be concluded that, bio-enhancers have proved to potential in case of curd weight, curd diameter, stem diameter, stem length and yield of broccoli displayed highest value amongst the treatment of various combination viz., Panchgavya, Jivamritaand Vermiwash. The treatment (T1) Panchgavya (4\%) and (T4) Panchgavya (4\%)+Jivamrita (20\%)came out the best combination for growth and yield characters.

The revenue gained through organic tags is much more than inorganic. Therefore, even if the amount of produce is low, revenue generation is not affected. The emphasis nowadays is given to human health, soil health, environmental health and quality product instead of quantity. Hence, the treatment (T1) Panchgavya (4\%) and (T4) Panchgavya (4\%)+Jivamrita (20\%)can be recommended for organic cultivation of broccoli.

\section{References}

"Broccoli". Merriam-Webster's Collegiate Dictionary (11thed.). 2004. p. 156. ISBN978-0-87779-809-5. Retrieved 9 April 2014.

"Broccoli production in 2017, Crops/ Regions/ World list/Production Quantity (pick lists)". UN Food and Agriculture Organization, Corporate Statistical Database (FAOSTAT). 2018. Retrieved
27 June 2019".

Aktar, S., Noor, S., Rahman M., Sultana S. and Nandi S. K.(1996). Effect of organic manure and chemical fertilizer on the yield of broccoli. Bangladesh Society for Horticultural Science, 24(1\&2), 59-64.

Ashwanikumar A. Raut, Ashok D., Vaidya B. (2018). Panchgavya and cow products: A trail for the Holy Grail. J. of Ayurveda and integrative medicine 9: 64-66.

Bakang Kedumetse Kgasudi and Modiri Mantswe (2020). Cow Urine: A plant gowth enhancer, bio fertilizer, pesticide and antifungal agent. Int. J. Curr. Microbiol. App. Sci. 9(02):1294-1298.

Bhadra, R., Mehedi, M. N. H, Akter, S., Rouf, M. A. and Mohosina, F. (2019). Effect of cowdung and boron on growth and yield of broccoli (Brassica oleracea). Journal of Bioscience and Agriculture Research, 22(02), 1845-1851.

Bhalla R, Kanwar P, Dhiman SR, Jain R. Effect of biofertilizers and biostimulants on growth and flowering in standard carnation (Dianthus caryophyllus). J. Ornam. Hort., 2006b: 9(4): 282-285.

Chandini R. kumar (2015), Therapeutic Potential of Brassica oleracea Broccoli)-A Review-Int J Drug Dev\& Res: 7:2.

Chaudhari IA. Effect of different organic sources on growth and yield of summer greengram [Vigna radiata (L.) Wilczek]. M.Sc. (Agri.) Thesis (Unpublished) submitted to Sardarkrushinagar Dantiwada Agricultural University, Sardarkrushinagar (Gujarat), 2012.

Deepali Tiwari Pandey (2010). Vegetables and human nutrition. Agropedia. 
Dhama K, Khurana SK, Karthik K, Tiwari R, Malik YPS and Chauhan RS. (2014). Panchgavya: Immune enhancing and therapeutic perspectives. J. Immunopathol. 16(1\&2): 1-11.

Dutta A, Thevanathan R, Dinamani DS, Bhavani ILG. Effect of liquid fertilizer of some seaweeds on nodulation by rizobia in some legume seedlings. Seaweeds Res. Utilin2005; 27:81-85.

HameedSalihHammad, Ahmed Amir Murad AlMandalawi \& Ghassan Jaafar Hamdi (2019) Effect of manure on growth and yield of broccoli, International Journal of Vegetable Science, 25:4, 400406.

Dhama, K., Rathore R., Chauhan R.S.and Tomar S. (2005). Panchgavya (Cowpathy): An overview. International Journal of Cow Science, 1(1): 1-15.

Kaur P, Bhardwaj M, Babbar I. Effect of vermicompost and Vermiwash on growth of vegetables. Res. J. Animal, Veterinary and Fishery Sci. 2015; 3(4)9-12.

Khomami MA. The effect of liquid bio-fertilizer (Vermiwash) in foliar application on Dieffenbachia and Aglaonema nutrition and growth indexes. J. Agric. Sci., 2004; 1(4):175-187.

Kumar R, Deka B, Roy C. Effect of bioregulators on vegetative growth, flowering and corm production in gladiolus cv. Candyman. J. Ornam. Hort., 2010; 13(1): 35-40.

Kumar S., Trivedi H., Sah R., VermaA. K. and Yadav A. (2018).

Mahmd A. Shekh, Ratilal K. Mathukia, Bhimjibhai K. Sagarka and Sunil K. Chhodovadia (2018). Evaluation of some cow based bio-enhancers and botanicals for organic cultivation of summer groundnut. Int. J. of economic plant. 5(1): 43-45.

Nath G, Singh K. Utilization of Vermiwash potential on certain summer vegetable crops. J. Central European Agric. 2009; 10(4):417-426.

Patel MM, Patel DM, Patel KM. Effect of Panchgavya on growth and yield of cow pea. An International e-Journal. 2013; 2(3):313-317.

Pizetta, L. C., Ferreira, M. E, Cruz, M. C. P. D. and Barbosa, J. C. (2005). Response of boron fertilization on broccoli, cauliflower and cabbage planted in sandy soil. Journal of Plant Nutrition, 26(12), 2587-2549

R.K. Pathakand R.A. Ram (2013).Bio-enhancers: A potential tool to improve soil fertility and plant health in organic production of horticultural crops. Progressive Horticulture, Vol. 45(2): 237-254.

RumezaHanif, ZafarIqbal, MudassarIqbal, ShaheenaHanif and MasoomaRasheed (2006). Use of vegetables as nutritional food: role in human health. Journal of Agricultural and Biological Science. Vol 01 (1): 22-26.

Saxena S, Garg V, Chauhan RS. Cow Urine Therapy: Promising cure for human ailments. The Indian Cow. 2004; 1:25-30.

Sharma, R., Shah, S., Adhikari, K., Shah, P., \&Shreshta, J. (2016). Effects of Cattle Urine and FYM on Soil Properties and Yield of Broccoli. Journal Of AgriSearch, 3(3), 157-160.

Sutharsan S, Mohottige LN. Effect of inorganic and organic nutrient sources on growth and nodulation of Glycine max. Research Journal of Agriculture and Forestry Sci. 2017; 5(9):1-5.

\section{How to cite this article:}

Ravi Prakash Mishra, Himanshu Trivedi, Deepali Bakshi, Vibhuti Gupta and Vivekanand Yadav. 2020. Evaluation of Cow Based Bio-Enhancers on Production of Broccoli (Brassica oleracea). Int.J.Curr.Microbiol.App.Sci. 9(12): 3099-3108.

doi: https://doi.org/10.20546/ijcmas.2020.912.368 